\title{
The Neutrophil Percentage-to-Albumin Ratio is Associated with All-Cause Mortality in Critically III Patients with Acute Myocardial Infarction
}

Ya Lin

The First Affiliated Hospital of Wenzhou Medical University

Yanhan Lin

The First Affiliated Hospital of Wenzhou Medical University

Juanqing Yue

Zhejiang University School of Medicine

Qianqian Zou ( $\square$ zou9407@126.com )

Wenzhou Peoples' Hospital

\section{Research Article}

Keywords: neutrophil percentage-to-albumin ratio, all-cause mortality, acute myocardial infarction

Posted Date: October 8th, 2021

DOI: https://doi.org/10.21203/rs.3.rs-877233/v1

License: (a) (i) This work is licensed under a Creative Commons Attribution 4.0 International License.

Read Full License

Version of Record: A version of this preprint was published at BMC Cardiovascular Disorders on March 18th, 2022. See the published version at https://doi.org/10.1186/s12872-022-02559-z. 


\section{Abstract}

\section{Aim}

In this study, we evaluated the utility of neutrophil percentage-to-albumin ratio (NPAR) in predicting in critically ill patients with acute myocardial infarction (AMI).

\section{Methods}

the information of patients were collected from Medical Information Mart for Intensive Care III (MIMIC III) database. Admission NPAR was calculated as neutrophil percentage divided by serum albumin. The endpoints of this study were 30-day, 90-day, 180-day, and 365-day all-cause mortality. Cox proportional hazards models and subgroup analyses were used to determine the relationship between admission NPAR and these endpoints.

\section{Results}

798 critically ill patients with AMI were enrolled in. After adjustments for age, race and gender, higher admission NPAR was associated with increased risk of 30-day, 90-day, 180-day, and 365-day all-cause mortality in critically ill patients with AMI. And after adjusting for possible confounding variables, two different trends have emerged. Stratified by tertiles, high admission NPAR was independently associated with 180-day and 365-day all-cause mortality in critically ill patients with AMI (tertile 3 vs. tertile 1: adjusted HR, 95\% Cl: 1.71,1.10-2.66, $\mathrm{p}<0.05 ; 1.66,1.10-2.51, \mathrm{p}<0.05)$. In other hand, stratified by quartiles, highest admission NPAR levels were independently associated with 90-day, 180-day and 365-day allcause mortality (quartile 4 vs. quartile 1: adjusted HR, 95\% Cl: 2.36,1.32-4.23, $p<0.05 ; 2.58,1.49-4.47$, $p<0.05 ; 2.61,1.56-4.37, p<0.05)$. ROC test showed that admission NPAR had a moderate ability to predict all-cause mortality of critically ill patients with AMI. No obvious interaction was found by subgroup analysis in most subgroups.

\section{Conclusions}

admission NPAR was an independent predictor for 180-day and 365-day all-cause mortality in critically ill patients with AMI.

\section{Introduction}

As it is well known, acute myocardial infarction (AMI) as a common cardiovascular disease continues to be the leading cause of hospital admission and mortality rate worldwide in the past years(1). Although potent antiplatelet agents and early revascularization has greatly reduced the occurrence of major 
adverse cardiovascular events in AMI patients(2), the prognosis of AMI patients is still an apparent problem worthy of our attention.

The inflammatory response participates in myocardial infarction (MI) area and left ventricular (LV) remodeling $(3,4)$. Neutrophil, the major participant in the inflammatory burst, mediates the inflammatory response to myocardial injury $(3,5)$. Albumin acts through its multiple binding sites and free radicalcapture properties, involved in antioxidant activities (6). It has been confirmed that low albumin level has a significant effect on the mortality and prognosis of AMI (7-9).

According to the previous studies, admission neutrophil percentage-to-albumin ratio (NPAR) was an independent predictor of in-hospital mortality in patients with acute ST-segment elevation myocardial infarction (STEMI) (10). In the another study, in critically ill patients with coronary artery disease (CAD), the higher NPAR level was closely correlated with the higher rate of 30-day, 90-day, and 365-day all-cause death(11). However,there is no study yet that reported the association between admission NPAR level and the all-cause mortality in critically ill patients with AMI. For all the above reasons, in this study we hypothesized that admission NPAR level could be a prognostic predictor of all-cause mortality in critically ill patients with AMI.

\section{Method}

\section{Source of data}

We conducted a retrospective cohort study, where the data were collected from a large, single-center critical care database called Medical Information Mart for Intensive Care III (MIMIC III)(12). MIMIC III is a public and freely available database and integrates comprehensive clinical data of patients admitted to the intensive care units (ICU) at the Beth Israel Deaconess Medical Center between 2001 and 2012. This database was approved by the Institutional Review Boards (IRB) of the Massachusetts Institute of Technology (MIT). After successfully completing the National Institutes of Health (NIH) Web-based training course and the Protecting Human Research Participants examination (no. 40683764), we were given the permission to extract data from MIMIC III.

\section{Population selection criteria}

All ICU inpatients with AMI diagnosed by ICD-9 diagnosis code were enrolled in this study. Exclusion criteria were as follows: (1) multiple ICU admissions; (2) aged < 18 years old; (3) had died before admission; (4) lack of the information of albumin and neutrophil percentage during ICU stay.

\section{Data extraction and definition of NPAR}

Data extraction from MIMIC III was accomplished using Structured Query Language (SQL) with the PostgreSQL tool (version 9.6). We extracted demographics, vital signs, comorbidities and medical history, laboratory parameters, scoring system, medication use, and clinical survival information. Age, gender and race were contained in demographics, and vital signs included heart rate, respiratory rate and mean blood 
pressure (MBP). Comorbidities and medical history included CAD, prior MI, atrial fibrillation (AF), chronic heart failure (CHF), chronic kidney disease (CDK), chronic obstructive pulmonary disease (COPD) and percutaneous transluminal coronary angioplasty/percutaneous coronary intervention (PTCA/PCI). Laboratory parameters were consisted of neutrophils, albumin, hemoglobin, white blood cell (WBC), prothrombin time (PT), platelet, red cell distribution width (RDW), potassium, sodium, creatinine, blood urea nitrogen (BUN), alanine aminotransferase (ALT), aspartate aminotransferase (AST), creatine kinasepeak (CK), MB isoenzyme of creatine kinase (CK-MB), and glucose. Scoring systems contains two important scoring scales-sequential organ failure assessment(SOFA) score(13) and simplified acute physiology score II (SAPS II)(14). In addition, the medication use of patients in this study would be shown in the baseline characteristics, including whether they have used aspirin, clopidogrel, metoprolol, angiotensin-converting enzyme inhibitors/angiotensin receptor blockers (ACEI/ARBs) or statins. The other extracted data have weight and urine output within 24 hours. All the laboratory parameters were firstlymeasured data after admission to the ICU. The endpoints of this study were 30-day, 90-day, 180-day, and 365-day all-cause mortality. We divided neutrophil percentage by albumin to get admission NPAR(10).

\section{Statistical Analysis}

All the patients with AMI in the study were stratified in term of admission NPAR tertiles. Data distribution of all continuous variables were tested using the Shapiro-Wilk test, and they were nonnormally distributed, and manifested as median and interquartile range (Q1-Q3). All categorical data was expressed as number and percentage. Kruskal-Wallis or Fisher's exact test was performed to evaluate statistical differences among different groups of NPAR.

Using Log-rank tests, survival rates of different groups were compared, and the Kaplan-Meier curves were built.

In order to evaluate the independent effect of admission NPAR on 30-day, 90-day, 180-day, and 365-day all-cause mortality, cox proportional hazard models were developed. The first tertile and quartile groups of admission NPAR were treated as the reference group, and the results were summarized as hazard ratios (HR) with 95\% confidence intervals $(\mathrm{Cl})$. In model I, age, race and gender were incorporated into adjustment. In model II, we further adjusted for age, gender, race, respiratory rate, MBP, heart rate, ALT, AST, CK-peak, CK-MB-peak, glucose, PT, hemoglobin, RDW, creatinine, potassium, sodium, BUN, WBC, platelet, CAD, AF, COPD, hypertension, diabetes, prior MI, CHF, CKD, stroke, SOFA and SAPS II. And P for trend was calculated. Subgroup analysis was conducted to estimate the effect of admission NPAR on 180-day all-cause mortality. And we got the $\mathrm{P}$ value for interaction.

Receiver-operating characteristic (ROC) curve was performed to measure the sensitivity and specificity of admission NPAR, as well as SOFA score. Moreover, the area under the curve (AUC) was calculated to estimate the quality of admission NPAR as a predictor of 365-day all-cause mortality. Statistical analyses were performed using EmpowerStats version 2.0 (http://www.empowerstats.com/cn/, X\&Y solutions, Inc., Boston, MA) and $R$ software version 3.4.3; $P$ value of $<0.05$ was considered to be statistically significant. 


\section{Result}

\section{Baseline characteristics of patients}

After reviewing the data of 62,699 critically ill patients, a total of 798 patients with AMI were enrolled in our study (Figure 1). Based on tertiles of admission NPAR level, participants were categorized into three groups (tertile 1: $<21.58$; tertile 2 : $\geq 21.58,<26.77$; and tertile 3 : $\geq 26.77$ ), and each group included $266 \mathrm{AMI}$ patients. The baseline characteristics were displayed in Table 1. Patients in the highest tertile of admission NPAR level were older than other groups, and most of them were white. In addition, they reported more medical history of AF, but less comorbidities of CAD, hypertension and CHF. Moreover, patients in the highest tertile of admission NPAR level were less likely to use aspirin, clopidogrel, metoprolol, ACEI/ARBs and statin, and to receive PTCA or PCI. Finally, they had lower MBP, weight, albumin, hemoglobin, urine output in 24 hours, and higher values of heart rate, neutrophils, WBC, PT, RDW, creatinine, BUN, ALT, AST, SAPS II and SOFA.

\section{Admission NPAR and outcome}

As it had been shown in Table 2, the overall length of ICU stay (LOS) was 3.69 days, and the overall inhospital, 30-day, 90-day, 180-day and 365-day all-cause mortality were 17.92\%, 19.67\%, 25.44\%, 29.82\% and $33.21 \%$, respectively. Furthermore, as admission NPAR levels increased, the all-cause death rate of inhospital, 30-day, 90-day, 180-day and 365-day were distinctly raised.

There were the survival curves of 30-day (log-rank, p<0,0001), 90-day (log-rank, $p<0,0001), 180$-day (logrank, $p<0,0001)$ and 365-day (log-rank, $p<0,0001)$ all-cause mortality stratified by the tertiles of admission NPAR, which were manifested in Figure 2. The trends indicated that the higher NPAR level had a worse survival probability.

\section{Admission NPAR as a predictor of the clinical endpoints}

In cox regression models, admission NPAR levels were stratified by tertiles and quartiles, to appraise whether admission NPAR was related to 30-day, 90-day, 180-day and 365-day all-cause mortality (Table 3). In model I, after adjustments for age, race and gender, higher admission NPAR was associated with increased risk of all-cause mortality. In model II, age, gender, race, respiratory rate, MBP, heart rate, ALT, AST, CK-peak, CK-MB-peak, glucose, PT, hemoglobin, RDW, creatinine, potassium, sodium, BUN, WBC, platelet, CAD, AF, COPD, hypertension, diabetes, prior MI, CHF, CKD, stroke, SOFA and SAPS II were incorporated into the regression model.There was a prominent correlation between high admission NPAR, 180-day and 365-day all-cause mortality (tertile 3 vs. tertile 1: adjusted HR, 95\% Cl: 1.71,1.10-2.66, $p<0.05$; 1.66,1.10-2.51, $\mathrm{p}<0.05)$. However, the relationship between admission NPAR ,30-day and 90-day all-cause mortality was not as relevant as the other groups. Unexpectedly, a merely different trend was observed in admission NPAR levels stratified by quartiles; highest admission NPAR levels were independently associated with 90-day, 180-day and 365-day all-cause mortality (quartile 4 vs. quartile 1: adjusted HR, $95 \%$ Cl: 2.36,1.32-4.23; 2.58,1.49-4.47; 2.61,1.56-4.37, p<0.05). 
The ROC test was employed to measure the sensitivity and specificity of admission NPAR with an AUC of 0.6421 (95\% Cl 0.6016-0.6826, p<0.0001). Then the AUC area of admission NPAR was compared with SAPS II and SOFA score. There was no difference between NPAR and SOFA. Thus, it ascertained the quality of NPAR as a reliable predictor of 365-day all-cause mortality (Figure 3).

\section{Subgroup Analysis}

In most subgroups, no significant interaction between admission NPAR and 180-day all-cause mortality was observed (Table 4). Patients with high values of heart rate SAPS II, ICU LOS and age had higher risks of all-cause mortality for high admission NPAR.

\section{Discussion}

The study indicated that admission NPAR was an independent factor of 30-day, 90-day, 180-day, and 365day all-cause mortality in critically ill patients with AMI, despite adjustment for age, race and gender. However, after adjustments for more potential confounders, admission NPAR was merely associated with 180-day, and 365-day all-cause mortality. Based on ROC curves, NPAR had a moderate ability to predict all-cause mortality of critically ill patients with AMI. Furthermore, subgroup analysis illustrated that there was no evident interaction in most subgroups.

Inflammation is a hallmark of atherosclerosis where immune cells, especially monocytes and white blood cells, together with cytokines and phospholipids contribute to trigger the inflammatory reaction $(5,15)$. The pervious study indicated that neutrophils, as an important member of white blood cells, played a significant role in coronary atherosclerosis and the formation of $\operatorname{AMI}(16,17)$. Meissner, J. et al(18) found that high neutrophil count was associated with increased risk for AMI in patients presenting to the emergence department with chest pain. The findings hinted that neutrophil accumulation was a strong predictor of all-cause mortality in patients with $\operatorname{AMI}(18,19)$

All the time, albumin has been considered as an indicator of nutritional status. However, the current study showed that there was a certain correlation between albumin and inflammation(7, 20, 21). Serum albumin levels had been affirmed to be inversely related to occurrence of ischemic heart disease ${ }^{21}$. Low serum albumin level was an independent predictor of in-hospital mortality in patients with acute coronary syndrome $(A C S)(7,22)$. Furthermore, a significant interaction was found between low serum albumin level and first incident $\mathrm{AMI}(23)$ and there was a evident correlation between low serum albumin level longterm mortality in patients with STEMI undergoing $\mathrm{PCI}(24)$ and patients with unstable angina pectoris (UAP) or non-ST elevation myocardial infarction (NSTEMI)(25).

The previous studies has demonstrated the prognosis value of NPAR in other clinical events including severe sepsis or septic shock(26), acute kidney injury(27) and cardiogenic shock(28). Sun, T. N. et al(11) documented that NPAR was an independent risk factor in critically ill patients with CAD. In term of the above study, we were curious about that NPAR would have same outcomes in AMI as it did in chronic CAD. The previous study identified that admission NPAR was an independent predictor of in-hospital 
mortality in patients with STEMI. Based on this, we investigated the impact of admission NPAR on the short-term and long-term risk of death in AMI patients. Our study showed that higher admission NPAR was only associated with increased risks of 180-day and 365-day all-cause mortality and may be an independent marker for long-term all-cause mortality in critically ill patients with AMI. According to the AUC area, admission NPAR had a moderate predictive ability in critically ill patients with AMI.

Compared with SOFA and SAPS II, the capacity of admission NPAR in predicting the risk of death was as well as SOFA though its effectiveness was not so adequate than SAPS II. But on account of the test methods for neutrophil percentage and albumin are economical and practical, admission NPAR would permit it possible to quickly evaluate the risk of death in critically ill patients with AMI. Especially, it has precious clinical utility for areas with underdeveloped economy and poor medical conditions.

\section{Limitation}

This study was a single-center retrospective study, the selection bias was inevitable. All data came from a publicly open clinical database, so it was difficult to extract some important variables, such as the history of smoking and drinking. Since both neutrophil percentage and albumin change dynamically, the study just chose admission NPAR measured at the first time after admission. Random error maybe inevitable. Due to missing values of more than $20 \%$, it was difficult to obtain information about some important clinical or laboratory variables.

\section{Conclusion}

Our study suggests that higher admission NPAR was independently associated with 180-day and 365-day all-cause mortality in critically ill patients with AMI. NPAR may be a clinical maker to predict risk stratification in patients with $\mathrm{AMI}$ and further to offer the Individualized treatment services.

\section{Abbreviations}

ACEl, angiotensin-converting enzyme inhibitor; ACS, acute coronary syndrome; AF, atrial fibrillation; ALT, alanine aminotransferase; AMI, acute myocardial infarction; ARB, angiotensin receptor blocker; AST, aspartate aminotransferase; $A U C$, area under the curve; BUN, blood urea nitrogen; CAD, coronary artery disease; $\mathrm{CDK}$, chronic kidney disease; $\mathrm{CHF}$, chronic heart failure; $\mathrm{Cl}$, confidence interval; $\mathrm{CK}$, creatine kinase-peak; CK-MB, MB isoenzyme of creatine kinase; COPD, chronic obstructive pulmonary disease; HR, hazard ratios; ICU, intensive care units; IRB, Institutional Review Boards; LOS, length of stay; MBP, mean blood pressure; MI, myocardial infarction; MIMIC III, Medical Information Mart for Intensive Care III; MIT, Massachusetts Institute of Technology; NIH, National Institutes of Health; NPAR, neutrophil percentage-toalbumin ratio; NSTEMI, non-ST elevation myocardial infarction; $\mathrm{PCl}$, percutaneous coronary intervention; PT, prothrombin time; PTCA, percutaneous transluminal coronary angioplasty; RDW, red cell distribution width; ROC, receiver-operating characteristic; SAPS II, simplified acute physiology score II; SOFA, 
sequential organ failure assessment; SQL, Structured Query Language; STEMI, ST-segment elevation myocardial infarction; UAP, unstable angina pectoris; WBC, white blood cell.

\section{Declarations}

Ethics approval and consent to participate:

Not applicable.

\section{Consent for publication:}

Not applicable.

\section{Availability of data and materials}

Not applicable.

\section{Competing interests:}

The authors have no relevant affiliations or financial involvement with any organization or entity with a financial interest in or financial conflict with the subject matter or materials discussed in the manuscript. This includes employment, consultancies, honoraria, stock ownership or options, expert testimony, grants or patents received or pending, or royalties.

\section{Funding:}

None.

\section{Authors' contributions:}

Study concept and design: Ya Lin and Qianqian Zou;

Acquisition of data: Yanhan Linand Juanqing Yue;

Drafting of the manuscript: Ya Lin and Yanhan Lin;

Statistical analysis: Ya Lin;

Study supervision: Juanqing Yue and Qianqian Zou;

All authors contributed to the manuscript for important intellectual content and approved the submission.

\section{Acknowledgements}

MIMIC is made available largely through the work of researchers at the MIT Laboratory for Computational Physiology and collaborating research groups. 
Our work is supported by grants from the National Institute of Biomedical Imaging and Bioengineering (NIBIB) of the National Institutes of Health $(\mathrm{NIH})$ under award numbers R01-EB001659 (2003-2013) and R01-EB017205 (2014-2018).

\section{References}

1. Reed GW, Rossi JE, Cannon CP. Acute myocardial infarction. Lancet. 2017;389(10065):197-210.

2. Suh JW, Mehran R, Claessen BE, Xu K, Baber U, Dangas G, et al. Impact of in-hospital major bleeding on late clinical outcomes after primary percutaneous coronary intervention in acute myocardial infarction the HORIZONS-AMI (Harmonizing Outcomes With Revascularization and Stents in Acute Myocardial Infarction) trial. J Am Coll Cardiol. 2011;58(17):1750-6.

3. Ong SB, Hernandez-Resendiz S, Crespo-Avilan GE, Mukhametshina RT, Kwek XY, Cabrera-Fuentes HA, et al. Inflammation following acute myocardial infarction: Multiple players, dynamic roles, and novel therapeutic opportunities. Pharmacol Ther. 2018;186:73-87.

4. Granger $\mathrm{CB}$, Kochar A. Understanding and Targeting Inflammation in Acute Myocardial Infarction: An Elusive Goal. J Am Coll Cardiol. 2018;72(2):199-201.

5. Ruparelia N, Chai JT, Fisher EA, Choudhury RP. Inflammatory processes in cardiovascular disease: a route to targeted therapies. Nat Rev Cardiol. 2017;14(5):314.

6. Roche M, Rondeau P, Singh NR, Tarnus E, Bourdon E. The antioxidant properties of serum albumin. FEBS Lett. 2008;582(13):1783-7.

7. Gonzalez-Pacheco H, Amezcua-Guerra LM, Sandoval J, Martinez-Sanchez C, Ortiz-Leon XA, PenaCabral MA, et al. Prognostic Implications of Serum Albumin Levels in Patients With Acute Coronary Syndromes. Am J Cardiol. 2017;119(7):951-8.

8. Wada H, Dohi T, Miyauchi K, Shitara J, Endo H, Doi S, et al. Impact of serum albumin levels on longterm outcomes in patients undergoing percutaneous coronary intervention. Heart Vessels. 2017;32(9):1085-92.

9. Plakht $Y$, Gilutz $H$, Shiyovich A. Decreased admission serum albumin level is an independent predictor of long-term mortality in hospital survivors of acute myocardial infarction. Soroka Acute Myocardial Infarction II (SAMI-II) project. International Journal of Cardiology. 2016;219:20-4.

10. Cui HH, Ding XS, Li WP, Chen H, Li HW, Data CBFH. The Neutrophil Percentage to Albumin Ratio as a New Predictor of In-Hospital Mortality in Patients with ST-Segment Elevation Myocardial Infarction. Med Sci Monitor. 2019;25:7845-52.

11. Sun TN, Shen H, Guo QY, Yang JQ, Zhai GY, Zhang JR, et al. Association between Neutrophil Percentage-to-Albumin Ratio and All-Cause Mortality in Critically III Patients with Coronary Artery Disease. Biomed Res Int. 2020;2020.

12. Johnson AE, Pollard TJ, Shen L, Lehman LW, Feng M, Ghassemi M, et al. MIMIC-III, a freely accessible critical care database. Sci Data. 2016;3:160035. 
13. Ferreira FL, Bota DP, Bross A, Melot C, Vincent JL. Serial evaluation of the SOFA score to predict outcome in critically ill patients. JAMA. 2001;286(14):1754-8.

14. Le Gall JR, Lemeshow S, Saulnier F. A new Simplified Acute Physiology Score (SAPS II) based on a European/North American multicenter study. JAMA. 1993;270(24):2957-63.

15. Hansson GK. Inflammation, atherosclerosis, and coronary artery disease. N Engl J Med. 2005;352(16):1685-95.

16. Chistiakov DA, Grechko AV, Myasoedova VA, Melnichenko AA, Orekhov AN. The role of monocytosis and neutrophilia in atherosclerosis. J Cell Mol Med. 2018;22(3):1366-82.

17. Silvestre-Roig C, Braster Q, Ortega-Gomez A, Soehnlein O. Neutrophils as regulators of cardiovascular inflammation. Nature Reviews Cardiology. 2020;17(6):327-40.

18. Meissner J, Irfan A, Twerenbold R, Mueller S, Reiter M, Haaf P, et al. Use of Neutrophil Count in Early Diagnosis and Risk Stratification of AMI. Am J Med. 2011;124(6):534-42.

19. Kyne L, Hausdorff JM, Knight E, Dukas L, Azhar G, Wei JY. Neutrophilia and congestive heart failure after acute myocardial infarction. Am Heart J. 2000;139(1 Pt 1):94-100.

20. Don BR, Kaysen G. Serum albumin: relationship to inflammation and nutrition. Semin Dial. 2004;17(6):432-7.

21. Arques S. Human serum albumin in cardiovascular diseases. Eur J Intern Med. 2018;52:8-12.

22. Zhu L, Chen M, Lin X. Serum albumin level for prediction of all-cause mortality in acute coronary syndrome patients: a meta-analysis. Biosci Rep. 2020;40(1).

23. He YM, Yang Q, Yang XJ, Zhao X, Xu HF, Qian YX. Serum albumin concentrations, effect modifiers and first incident acute myocardial infarction: A cross-sectional study of 1552 cases and 6680 controls. Clin Chim Acta. 2016;454:49-56.

24. Oduncu V, Erkol A, Karabay CY, Kurt M, Akgun T, Bulut M, et al. The prognostic value of serum albumin levels on admission in patients with acute ST-segment elevation myocardial infarction undergoing a primary percutaneous coronary intervention. Coronary Artery Dis. 2013;24(2):88-94.

25. Polat N, Oylumlu M, Isik MA, Arslan B, Ozbek M, Demir M, et al. Prognostic Significance of Serum Albumin in Patients With Acute Coronary Syndrome. Angiology. 2020;71(10):903-8.

26. Gong YQ, Li DW, Cheng BH, Ying BY, Wang BJ. Increased neutrophil percentage-to-albumin ratio is associated with all-cause mortality in patients with severe sepsis or septic shock. Epidemiol Infect. 2020;148.

27. Wang BJ, Li DW, Cheng BH, Ying BY, Gong YQ. The Neutrophil Percentage-to-Albumin Ratio Is Associated with All-Cause Mortality in Critically III Patients with Acute Kidney Injury. Biomed Res Int. 2020;2020.

28. Yu Y, Liu Y, Ling XY, Huang RH, Wang SY, Min J, et al. The Neutrophil Percentage-to-Albumin Ratio as a New Predictor of All-Cause Mortality in Patients with Cardiogenic Shock. Biomed Res Int. 2020;2020. 


\section{Tables}

Table 1: Characteristics of study patients by NPAR tertiles. 


\begin{tabular}{|c|c|c|c|c|}
\hline \multirow[t]{2}{*}{ Characteristics } & Tertile $1(n=266)$ & Tertile $2(n=266)$ & Tertile $3(n=266)$ & \\
\hline & $<21.58$ & $\geq 21.58,<26.77$ & $\geq 26.77$ & $P$ value \\
\hline Age (years) & $\begin{array}{l}67.50(57.00- \\
77.75)\end{array}$ & $\begin{array}{l}69.00(58.00- \\
79.00)\end{array}$ & $\begin{array}{l}73.00(63.00- \\
80.00)\end{array}$ & 0.001 \\
\hline Male, n (\%) & 179 (67.29\%) & $165(62.03 \%)$ & $160(60.15 \%)$ & 0.209 \\
\hline \multicolumn{2}{|l|}{ Race, n (\%) } & & & 0.032 \\
\hline White & 179 (67.29\%) & $160(60.15 \%)$ & 179 (67.29\%) & \\
\hline Black & $21(7.89 \%)$ & $17(6.39 \%)$ & 8 (3.01\%) & \\
\hline Other & $66(24.81 \%)$ & 89 (33.46\%) & 79 (29.70\%) & \\
\hline $\begin{array}{l}\text { Heart } \\
\text { rate (beats/minute) }\end{array}$ & $95.77 \pm 25.54$ & $101.57 \pm 26.39$ & $105.51 \pm 24.40$ & $<0.001$ \\
\hline $\mathrm{MBP}(\mathrm{mmHg})$ & $73.15 \pm 34.18$ & $67.20 \pm 28.90$ & $62.95 \pm 29.72$ & $<0.001$ \\
\hline $\begin{array}{l}\text { Respiratory rate } \\
\text { (beats/minute) }\end{array}$ & $24.24 \pm 8.82$ & $24.33 \pm 9.81$ & $25.47 \pm 9.94$ & 0.240 \\
\hline Weight(kg) & $81.94 \pm 19.31$ & $79.13 \pm 19.65$ & $77.97 \pm 19.72$ & 0.017 \\
\hline CAD & $192(72.18 \%)$ & 207 (77.82\%) & 146 (54.89\%) & $<0.001$ \\
\hline Prior MI & 15 (5.64\%) & $18(6.77 \%)$ & $13(4.89 \%)$ & 0.645 \\
\hline $\mathrm{AF}$ & 67 (25.19\%) & $80(30.08 \%)$ & $100(37.59 \%)$ & 0.008 \\
\hline Hypertension & $136(51.13 \%)$ & $118(44.36 \%)$ & 91 (34.21\%) & $<0.001$ \\
\hline Diabetes & 75 (28.20\%) & $76(28.57 \%)$ & $80(30.08 \%)$ & 0.880 \\
\hline $\mathrm{CHF}$ & 105 (39.47\%) & $136(51.13 \%)$ & 135 (50.75\%) & 0.009 \\
\hline CKD & $29(10.90 \%)$ & 37 (13.91\%) & 42 (15.79\%) & 0.251 \\
\hline Stroke & $6(2.26 \%)$ & $10(3.76 \%)$ & $14(5.26 \%)$ & 0.190 \\
\hline COPD & $4(1.50 \%)$ & $2(0.75 \%)$ & $8(3.01 \%)$ & 0.131 \\
\hline PTCA/PCI & 187 (70.30\%) & 173 (65.04\%) & 125 (46.99\%) & $<0.001$ \\
\hline \multicolumn{5}{|l|}{ Laboratory parameters } \\
\hline $\begin{array}{l}\text { Neutrophil percentage } \\
(\%)\end{array}$ & $\begin{array}{l}71.20(61.35- \\
78.95)\end{array}$ & $\begin{array}{l}84.00(77.60- \\
88.07)\end{array}$ & $\begin{array}{l}86.00(80.85- \\
89.77)\end{array}$ & $<0.001$ \\
\hline Albumin (g/dL) & $3.80(3.50-4.10)$ & $3.50(3.20-3.70)$ & $2.70(2.40-3.00)$ & $<0.001$ \\
\hline Hemoglobin (g/dL) & $\begin{array}{l}13.35(11.90- \\
14.57)\end{array}$ & $\begin{array}{l}12.60(11.10- \\
14.10)\end{array}$ & $\begin{array}{l}11.35(10.10- \\
12.97)\end{array}$ & $<0.001$ \\
\hline WBC $\left(10^{9} / \mathrm{L}\right)$ & $10.30(7.50-13.80)$ & $12.50(9.60-16.70)$ & $13.70(10.10-$ & $<0.001$ \\
\hline
\end{tabular}


17.50)

\begin{tabular}{|c|c|c|c|c|}
\hline & & & & \\
\hline PT (seconds) & $\begin{array}{l}13.30(12.50- \\
14.00)\end{array}$ & $\begin{array}{l}13.70(12.90- \\
15.10)\end{array}$ & $\begin{array}{l}14.50(13.30- \\
16.88)\end{array}$ & $<0.001$ \\
\hline Platelet $\left(10^{9} / \mathrm{L}\right)$ & $\begin{array}{l}242.50(188.25- \\
301.75)\end{array}$ & $\begin{array}{l}252.00(192.25- \\
299.00)\end{array}$ & $\begin{array}{l}230.50(170.25- \\
302.75)\end{array}$ & 0.113 \\
\hline RDW (\%) & $\begin{array}{l}13.60(13.10- \\
14.50)\end{array}$ & $\begin{array}{l}13.70(13.00- \\
14.50)\end{array}$ & $\begin{array}{l}14.20(13.30- \\
15.60)\end{array}$ & $<0.001$ \\
\hline Potassium (mmol/L) & $4.20(3.90-4.60)$ & $4.10(3.80-4.50)$ & $4.20(3.80-4.70)$ & 0.216 \\
\hline Sodium (mmol/L) & $\begin{array}{l}139.00(137.00- \\
141.00)\end{array}$ & $\begin{array}{l}138.00(135.25- \\
141.00)\end{array}$ & $\begin{array}{l}139.00(134.25- \\
141.00)\end{array}$ & 0.036 \\
\hline Creatinine (mEq/L) & $1.10(0.90-1.40)$ & $1.10(0.90-1.40)$ & $1.20(1.00-1.70)$ & $<0.001$ \\
\hline BUN (mg/dL) & $\begin{array}{l}20.00(15.00- \\
28.00)\end{array}$ & $\begin{array}{l}21.00(15.00- \\
30.25)\end{array}$ & $\begin{array}{l}27.00(18.50- \\
43.50)\end{array}$ & $<0.001$ \\
\hline $\operatorname{ALT}(\mathrm{U} / \mathrm{L})$ & $\begin{array}{l}30.21(20.00- \\
62.75)\end{array}$ & $\begin{array}{l}37.00(21.00- \\
68.75)\end{array}$ & $\begin{array}{l}42.33(22.00- \\
79.00)\end{array}$ & 0.024 \\
\hline AST (U/L) & $\begin{array}{l}52.00(26.25- \\
124.63)\end{array}$ & $\begin{array}{l}74.50(34.24- \\
174.00)\end{array}$ & $\begin{array}{l}77.70(38.00- \\
196.37)\end{array}$ & 0.001 \\
\hline CK-peak (U/L) & $\begin{array}{l}743.30(292.70- \\
1756.00)\end{array}$ & $\begin{array}{l}1088.50(329.25- \\
2427.20)\end{array}$ & $\begin{array}{l}702.00(252.15- \\
1983.00)\end{array}$ & 0.052 \\
\hline CK-MB-peak (U/L) & $\begin{array}{l}53.00(14.00- \\
181.00)\end{array}$ & $\begin{array}{l}72.00(13.00- \\
227.50)\end{array}$ & $\begin{array}{l}37.00(11.00- \\
150.00)\end{array}$ & 0.092 \\
\hline Glucose $(\mathrm{mg} / \mathrm{dL})$ & $\begin{array}{l}143.00(115.25- \\
191.75)\end{array}$ & $\begin{array}{l}148.00(122.25- \\
207.25)\end{array}$ & $\begin{array}{l}152.00(119.25- \\
213.75)\end{array}$ & 0.254 \\
\hline Scoring systems & & & & \\
\hline SAPS II & $\begin{array}{l}34.00(25.00- \\
44.00)\end{array}$ & $\begin{array}{l}36.00(28.00- \\
48.00)\end{array}$ & $\begin{array}{l}43.00(35.00- \\
54.00)\end{array}$ & $<0.001$ \\
\hline SOFA & $3.00(1.00-2.00)$ & $4.00(3.00-5.00)$ & $6.00(7.00-10.00)$ & $<0.001$ \\
\hline Medication use, n (\%) & & & & \\
\hline Aspirin & $214(80.45 \%)$ & $221(83.08 \%)$ & $172(64.66 \%)$ & $<0.001$ \\
\hline Clopidogre & $132(49.62 \%)$ & $148(55.64 \%)$ & $117(43.98 \%)$ & 0.027 \\
\hline Metoprolol & $209(78.57 \%)$ & 197 (74.06\%) & $156(58.65 \%)$ & $<0.001$ \\
\hline ACEl/ARBs & $156(58.65 \%)$ & $171(64.29 \%)$ & $100(37.59 \%)$ & $<0.001$ \\
\hline Statin & $201(75.56 \%)$ & 199 (74.81\%) & $156(58.65 \%)$ & $<0.001$ \\
\hline Urine output (ml/24h) & $\begin{array}{l}2116.00(1424.00- \\
3074.00)\end{array}$ & $\begin{array}{l}1825.00(1090.00- \\
2718.75)\end{array}$ & $\begin{array}{l}1377.50 \\
2275.25)\end{array}$ & $<0.001$ \\
\hline
\end{tabular}


Continuous variables are presented as mean (SD) for normally distributed variables or median (interquartile range) for non-normally distributed variables, whereas categorical variables are presented as number (percentage).

MBP: mean blood pressure; CAD: coronary artery disease; prior MI: prior myocardial infarction; AF: atrial fibrillation; CHF: chronic heart failure; CDK: chronic kidney disease ;COPD: chronic obstructive pulmonary disease; PTCA/PCI: Percutaneous transluminal coronary angioplasty/percutaneous coronary intervention; WBC: white blood cell; PT: prothrombin time; RDW: Red Cell Distribution Width; BUN: blood urea nitrogen; ALT: alanine aminotransferase; AST: aspartate aminotransferase; CK: creatine kinase; CK-MB: MB isoenzyme of creatine kinase; SAPS II: simplified acute physiology score II; SOFA: sequential organ failure assessment score; ACEI/ARBs: angiotensin-converting enzyme inhibitor/angiotensin receptor blockers.

Table 2: Outcome of the study patients by NPAR tertiles.

\begin{tabular}{|c|c|c|c|c|c|}
\hline \multirow[t]{2}{*}{ outcomes } & \multirow[t]{2}{*}{ Total(n=798) } & $\begin{array}{l}\text { Tertile } \\
1(n=266)\end{array}$ & $\begin{array}{l}\text { Tertile } \\
2(n=266)\end{array}$ & $\begin{array}{l}\text { Tertile } \\
3(n=266)\end{array}$ & \multirow[t]{2}{*}{$P$ value } \\
\hline & & $<21.58$ & $\geq 21.58,<26.77$ & $\geq 26.77$ & \\
\hline ICU LOS (day) & $\begin{array}{l}3.69(0.51- \\
100.12)\end{array}$ & $\begin{array}{l}2.57(0.58- \\
49.13)\end{array}$ & $\begin{array}{l}3.71(0.59- \\
100.12)\end{array}$ & $\begin{array}{l}5.33(0.51- \\
52.81)\end{array}$ & $<0.001$ \\
\hline \multicolumn{6}{|c|}{ all-cause mortality } \\
\hline In-hospital & $143(17.92 \%)$ & $32(12.03 \%)$ & $38(14.29 \%)$ & $73(27.44 \%)$ & $<0.001$ \\
\hline $\begin{array}{l}\text { 30-day } \\
\text { mortality }\end{array}$ & 157 (19.67\%) & $35(13.16 \%)$ & $48(18.05 \%)$ & $74(27.82 \%)$ & $<0.001$ \\
\hline $\begin{array}{l}\text { 90-day } \\
\text { mortality }\end{array}$ & 203 (25.44\%) & $44(16.54 \%)$ & $58(21.80 \%)$ & $101(37.97 \%)$ & $<0.001$ \\
\hline $\begin{array}{l}\text { 180-day } \\
\text { mortality }\end{array}$ & $238(29.82 \%)$ & $50(18.80 \%)$ & $73(27.44 \%)$ & $115(43.23 \%)$ & $<0.001$ \\
\hline $\begin{array}{l}\text { 365-day } \\
\text { mortality }\end{array}$ & 265 (33.21\%) & $58(21.80 \%)$ & $84(31.58 \%)$ & 123 (46.24\%) & $<0.001$ \\
\hline
\end{tabular}

Data are expressed as count (percentage) for categorical variables and median (interquartile range) for continuous variables. ICU LOS: length of ICU stay.

Table 3: The association between all-cause mortality and NPAR. 


\begin{tabular}{|c|c|c|c|c|c|c|}
\hline & \multicolumn{2}{|l|}{ Non-adjusted } & \multicolumn{2}{|l|}{ Model I } & \multicolumn{2}{|l|}{ Model II } \\
\hline NPAR & HR (95\% Cls) & $P$ value & HR (95\% Cls) & $P$ value & HR (95\% Cls) & $\begin{array}{l}P \\
\text { value }\end{array}$ \\
\hline \multicolumn{7}{|c|}{ 30-day all-cause mortality } \\
\hline \multicolumn{7}{|l|}{ Tertiles } \\
\hline$<21.58$ & 1.0 & & 1.0 & & 1.0 & \\
\hline $\begin{array}{l}\geq 21.58 \\
<26.77\end{array}$ & $\begin{array}{l}1.38(0.89 \\
2.13)\end{array}$ & 0.1506 & $\begin{array}{l}1.27(0.82 \\
1.96)\end{array}$ & 0.2917 & $\begin{array}{l}0.99(0.60 \\
1.66)\end{array}$ & 0.9826 \\
\hline$\geq 26.77$ & $\begin{array}{l}2.29(1.53 \\
3.43)\end{array}$ & $<0.0001$ & $\begin{array}{l}2.07(1.38 \\
3.12)\end{array}$ & 0.0005 & $\begin{array}{l}1.29(0.77 \\
2.17)\end{array}$ & 0.3262 \\
\hline$P$ for trend & $<0.0001$ & & 0.0002 & & 0.5418 & \\
\hline \multicolumn{7}{|l|}{ Quartiles } \\
\hline$<20.49$ & 1.0 & & 1.0 & & 1.0 & \\
\hline $\begin{array}{l}\geq 20.49 \\
<23.94\end{array}$ & $\begin{array}{l}1.55(0.91 \\
2.65)\end{array}$ & 0.1078 & $\begin{array}{l}1.43(0.84 \\
2.45)\end{array}$ & 0.1912 & $\begin{array}{l}1.73(0.91 \\
3.30)\end{array}$ & 0.0956 \\
\hline $\begin{array}{l}\geq 23.94 \\
<28.33\end{array}$ & $\begin{array}{l}2.07(1.24 \\
3.45)\end{array}$ & 0.0056 & $\begin{array}{l}1.96(1.17 \\
3.28)\end{array}$ & 0.0109 & $\begin{array}{l}1.50(0.80 \\
2.83)\end{array}$ & 0.2101 \\
\hline$\geq 28.33$ & $\begin{array}{l}2.87(1.76, \\
4.69)\end{array}$ & $<0.0001$ & $\begin{array}{l}2.54(1.54, \\
4.18)\end{array}$ & 0.0002 & $\begin{array}{l}2.01(1.05 \\
3.87)\end{array}$ & 0.0354 \\
\hline$P$ for trend & $<0.0001$ & & $<0.0001$ & & 0.2698 & \\
\hline \multicolumn{7}{|c|}{ 90-day all-cause mortality } \\
\hline \multicolumn{7}{|l|}{ Tertiles } \\
\hline$<21.58$ & 1.0 & & 1.0 & & 1.0 & \\
\hline $\begin{array}{l}\geq 21.58 \\
<26.77\end{array}$ & $\begin{array}{l}1.34(0.91 \\
1.98)\end{array}$ & 0.1439 & $\begin{array}{l}1.22(0.82, \\
1.81)\end{array}$ & 0.3200 & $\begin{array}{l}1.06(0.66 \\
1.70)\end{array}$ & 0.7952 \\
\hline$\geq 26.77$ & $\begin{array}{l}2.59(1.81 \\
3.68)\end{array}$ & $<0.0001$ & $\begin{array}{l}2.31(1.61, \\
3.31)\end{array}$ & $<0.0001$ & $\begin{array}{l}1.54(0.97 \\
2.46)\end{array}$ & 0.0701 \\
\hline$P$ for trend & $<0.0001$ & & $<0.0001$ & & 0.0893 & \\
\hline \multicolumn{7}{|l|}{ Quartiles } \\
\hline$<20.49$ & 1.0 & & 1.0 & & 1.0 & \\
\hline $\begin{array}{l}\geq 20.49 \\
<23.94\end{array}$ & $\begin{array}{l}1.60(1.00 \\
2.58)\end{array}$ & 0.0504 & $\begin{array}{l}1.48(0.92 \\
2.38)\end{array}$ & 0.1077 & $\begin{array}{l}1.86(1.04 \\
3.33)\end{array}$ & 0.0359 \\
\hline $\begin{array}{l}\geq 23.94 \\
<28.33\end{array}$ & $\begin{array}{l}1.85(1.16 \\
2.94)\end{array}$ & 0.0099 & $\begin{array}{l}1.75(1.09 \\
2.79)\end{array}$ & 0.0195 & $\begin{array}{l}1.41(0.78 \\
2.53)\end{array}$ & 0.2512 \\
\hline
\end{tabular}




\begin{tabular}{|c|c|c|c|c|c|c|}
\hline$\geq 28.33$ & $\begin{array}{l}3.39(2.21 \\
5.20)\end{array}$ & $<0.0001$ & $\begin{array}{l}2.97(1.92 \\
4.58)\end{array}$ & $<0.0001$ & $\begin{array}{l}2.36(1.32, \\
4.23)\end{array}$ & 0.0038 \\
\hline$P$ for trend & $<0.0001$ & & $<0.0001$ & & 0.0399 & \\
\hline \multicolumn{7}{|c|}{ 180-day all-cause mortality } \\
\hline \multicolumn{7}{|l|}{ Tertiles } \\
\hline$<21.58$ & 1.0 & & 1.0 & & 1.0 & \\
\hline $\begin{array}{l}\geq 21.58 \\
<26.77\end{array}$ & $\begin{array}{l}1.50(1.05 \\
2.15)\end{array}$ & 0.0273 & $\begin{array}{l}1.38(0.96 \\
1.98)\end{array}$ & 0.0821 & $\begin{array}{l}1.36(0.88 \\
2.11)\end{array}$ & 0.1660 \\
\hline$\geq 26.77$ & $\begin{array}{l}2.67(1.92, \\
3.73)\end{array}$ & $<0.0001$ & $\begin{array}{l}2.40(1.71 \\
3.36)\end{array}$ & $<0.0001$ & $\begin{array}{l}1.71(1.10 \\
2.66)\end{array}$ & 0.0165 \\
\hline P for trend & $<0.0001$ & & $<0.0001$ & & 0.0272 & \\
\hline \multicolumn{7}{|l|}{ Quartiles } \\
\hline$<20.49$ & 1.0 & & 1.0 & & 1.0 & \\
\hline $\begin{array}{l}\geq 20.49 \\
<23.94\end{array}$ & $\begin{array}{l}1.78(1.15, \\
2.76)\end{array}$ & 0.0092 & $\begin{array}{l}1.66(1.07 \\
2.57)\end{array}$ & 0.0236 & $\begin{array}{l}2.18(1.27 \\
3.75)\end{array}$ & 0.0048 \\
\hline $\begin{array}{l}\geq 23.94 \\
<28.33\end{array}$ & $\begin{array}{l}1.91 \\
2.95)\end{array}$ & 0.0036 & $\begin{array}{l}1.80(1.17 \\
2.79)\end{array}$ & 0.0080 & $\begin{array}{l}1.66(0.96 \\
2.88)\end{array}$ & 0.0698 \\
\hline$\geq 28.33$ & $\begin{array}{l}3.54(2.37 \\
5.29)\end{array}$ & $<0.0001$ & $\begin{array}{l}3.12(2.08 \\
4.68)\end{array}$ & $<0.0001$ & $\begin{array}{l}2.58(1.49, \\
4.47)\end{array}$ & 0.0007 \\
\hline$P$ for trend & $<0.0001$ & & $<0.0001$ & & 0.0150 & \\
\hline \multicolumn{7}{|c|}{ 365-day all-cause mortality } \\
\hline \multicolumn{7}{|l|}{ Tertiles } \\
\hline$<21.58$ & 1.0 & & 1.0 & & 1.0 & \\
\hline $\begin{array}{l}\geq 21.58 \\
<26.77\end{array}$ & $\begin{array}{l}1.50(1.08 \\
2.10)\end{array}$ & 0.0169 & $\begin{array}{l}1.38(0.99 \\
1.93)\end{array}$ & 0.0610 & $\begin{array}{l}1.40(0.93 \\
2.10)\end{array}$ & 0.1031 \\
\hline$\geq 26.77$ & $\begin{array}{l}2.52(1.85 \\
3.45)\end{array}$ & $<0.0001$ & $\begin{array}{l}2.22(1.62 \\
3.04)\end{array}$ & $<0.0001$ & $\begin{array}{l}1.66(1.10 \\
2.51)\end{array}$ & 0.0154 \\
\hline$P$ for trend & $<0.0001$ & & $<0.0001$ & & 0.0471 & \\
\hline \multicolumn{7}{|l|}{ Quartiles } \\
\hline$<20.49$ & 1.0 & & 1.0 & & 1.0 & \\
\hline $\begin{array}{l}\geq 20.49 \\
<23.94\end{array}$ & $\begin{array}{l}1.76(1.17 \\
2.65)\end{array}$ & 0.0064 & $\begin{array}{l}1.64(1.09 \\
2.46)\end{array}$ & 0.0182 & $\begin{array}{l}2.20(1.32, \\
3.66)\end{array}$ & 0.0024 \\
\hline $\begin{array}{l}\geq 23.94 \\
<28.33\end{array}$ & $\begin{array}{l}1.91(1.27 \\
2.86)\end{array}$ & 0.0018 & $\begin{array}{l}1.78(1.18 \\
2.67)\end{array}$ & 0.0056 & $\begin{array}{l}1.80(1.08 \\
3.00)\end{array}$ & 0.0250 \\
\hline$\geq 28.33$ & 3.39 (2.33, & $<0.0001$ & $\begin{array}{l}2.92(2.00 \\
\text { age } 16 / 26\end{array}$ & $<0.0001$ & 2.61 (1.56, & 0.0003 \\
\hline
\end{tabular}




\begin{tabular}{|llll|} 
& $4.95)$ & $4.28)$ & $4.37)$ \\
\hline P for trend & $<0.0001$ & $<0.0001$ & 0.0075 \\
\hline
\end{tabular}

HR: hazard ratio; Cl: confidence interval. Models were derived from Cox proportional hazard regression models.

Non-adjusted model adjust for: None

Adjust I model adjust for: Age; Gender; Race

Adjust II model adjust for: Age; Gender; Race; Respiratory rate; MBP; Heart rate; ALT; AST; CK-peak; CK-MBpeak; Glucose; PT; Hemoglobin; RDW; Creatinine; Potassium; Sodium; BUN; WBC; Platelet; CAD; AF; COPD; Hypertension; Diabetes; prior Ml; CHF; CKD; STROKE; SOFA; SAPS II

Table 4: The association between three NPAR groups and 180-day all-cause mortality in subgroup analysis. 


\begin{tabular}{|c|c|c|c|c|c|}
\hline & $\mathrm{N}$ & $\begin{array}{l}\text { NPAR } \\
<21.58\end{array}$ & & & $\begin{array}{l}\text { P for } \\
\text { interaction }\end{array}$ \\
\hline & & (reference) & HR (95\% Cls) & (10) & \\
\hline $\mathrm{AF}$ & & & & & 0.4736 \\
\hline No & 551 & 1.0 & $\begin{array}{l}1.42(0.90 \\
2.23)\end{array}$ & $\begin{array}{l}2.80(1.85 \\
4.26)\end{array}$ & \\
\hline Yes & 247 & 1.0 & $\begin{array}{l}1.55(0.86 \\
2.81)\end{array}$ & $\begin{array}{l}2.19(1.26 \\
3.82)\end{array}$ & \\
\hline $\mathrm{CHF}$ & & & & & 0.1939 \\
\hline No & 422 & 1.0 & $\begin{array}{l}1.18(0.68 \\
2.07)\end{array}$ & $\begin{array}{l}2.89(1.79 \\
4.67)\end{array}$ & \\
\hline Yes & 376 & 1.0 & $\begin{array}{l}1.60(0.99 \\
2.59)\end{array}$ & $\begin{array}{l}2.30(1.45 \\
3.65)\end{array}$ & \\
\hline CKD & & & & & 0.5369 \\
\hline No & 690 & 1.0 & $\begin{array}{l}1.54(1.04 \\
2.27)\end{array}$ & $\begin{array}{l}2.53(1.76 \\
3.64)\end{array}$ & \\
\hline Yes & 108 & 1.0 & $\begin{array}{l}1.21(0.47, \\
3.13)\end{array}$ & $\begin{array}{l}3.12(1.35 \\
7.22)\end{array}$ & \\
\hline COPD & & & & & 0.9520 \\
\hline No & 784 & 1.0 & $\begin{array}{l}1.50(1.04 \\
2.16)\end{array}$ & $\begin{array}{l}2.62(1.87 \\
3.67)\end{array}$ & \\
\hline Yes & 14 & 1.0 & $\begin{array}{l}2.42(0.15 \\
39.05)\end{array}$ & $\begin{array}{l}3.37(0.40 \\
28.33)\end{array}$ & \\
\hline CAD & & & & & 0.8694 \\
\hline No & 253 & 1.0 & $\begin{array}{l}1.72(0.92 \\
3.23)\end{array}$ & $\begin{array}{l}2.54(1.48 \\
4.36)\end{array}$ & \\
\hline Yes & 545 & 1.0 & $\begin{array}{l}1.45(0.94 \\
2.26)\end{array}$ & $\begin{array}{l}2.49(1.61, \\
3.83)\end{array}$ & \\
\hline Hypertension & & & & & 0.3855 \\
\hline No & 453 & 1.0 & $\begin{array}{l}1.19(0.74, \\
1.91)\end{array}$ & $\begin{array}{l}2.34(1.54 \\
3.55)\end{array}$ & \\
\hline Yes & 345 & 1.0 & $\begin{array}{l}1.95(1.11 \\
3.41)\end{array}$ & $\begin{array}{l}2.86(1.64, \\
4.98)\end{array}$ & \\
\hline Diabetes & & & & & 0.3603 \\
\hline No & 567 & 1.0 & $\begin{array}{l}1.36(0.90 \\
2.06)\end{array}$ & $\begin{array}{l}2.32(1.58 \\
3.40)\end{array}$ & \\
\hline
\end{tabular}




\begin{tabular}{|c|c|c|c|c|c|}
\hline Yes & 231 & 1.0 & $\begin{array}{l}1.99(0.96 \\
4.13)\end{array}$ & $\begin{array}{l}3.91(1.99, \\
7.70)\end{array}$ & \\
\hline Prior MI & & & & & 0.4050 \\
\hline No & 752 & 1.0 & $\begin{array}{l}1.54(1.06 \\
2.25)\end{array}$ & $\begin{array}{l}2.84(2.01, \\
4.02)\end{array}$ & \\
\hline Yes & 46 & 1.0 & $\begin{array}{l}1.09(0.33 \\
3.57)\end{array}$ & $\begin{array}{l}1.20(0.35 \\
4.13)\end{array}$ & \\
\hline Stroke & & & & & 0.4004 \\
\hline No & 768 & 1.0 & $\begin{array}{l}1.52(1.05 \\
2.20)\end{array}$ & $\begin{array}{l}\text { 2.75 (1.95, } \\
3.88)\end{array}$ & \\
\hline Yes & 30 & 1.0 & $\begin{array}{l}0.69(0.16 \\
2.91)\end{array}$ & $\begin{array}{l}0.92(0.24 \\
3.58)\end{array}$ & \\
\hline Clopidogre & & & & & 0.4357 \\
\hline No & 401 & 1.0 & $\begin{array}{l}1.22(0.75 \\
1.99)\end{array}$ & $\begin{array}{l}2.37(1.55 \\
3.61)\end{array}$ & \\
\hline Yes & 397 & 1.0 & $\begin{array}{l}1.97(1.14, \\
3.41)\end{array}$ & $\begin{array}{l}3.04(1.77 \\
5.20)\end{array}$ & \\
\hline Aspirin & & & & & 0.4040 \\
\hline No & 191 & 1.0 & $\begin{array}{l}0.98(0.47, \\
2.05)\end{array}$ & $\begin{array}{l}1.93(1.08 \\
3.46)\end{array}$ & \\
\hline Yes & 607 & 1.0 & $\begin{array}{l}1.73(1.14 \\
2.62)\end{array}$ & $\begin{array}{l}2.85(1.90 \\
4.28)\end{array}$ & \\
\hline Metoprolol & & & & & 0.8271 \\
\hline No & 236 & 1.0 & $\begin{array}{l}1.30(0.72 \\
2.35)\end{array}$ & $\begin{array}{l}1.98(1.17 \\
3.35)\end{array}$ & \\
\hline Yes & 562 & 1.0 & $\begin{array}{l}1.53(0.97 \\
2.41)\end{array}$ & $\begin{array}{l}2.59(1.68 \\
4.00)\end{array}$ & \\
\hline ACEI/ARBs & & & & & 0.3793 \\
\hline No & 371 & 1.0 & $\begin{array}{l}1.33(0.83 \\
2.14)\end{array}$ & $\begin{array}{l}2.21(1.48 \\
3.31)\end{array}$ & \\
\hline Yes & 427 & 1.0 & $\begin{array}{l}1.98(1.13, \\
3.47)\end{array}$ & $\begin{array}{l}2.19(1.19, \\
4.03)\end{array}$ & \\
\hline Statin & & & & & 0.2013 \\
\hline No & 242 & 1.0 & $\begin{array}{l}1.25(0.73 \\
2.15)\end{array}$ & $\begin{array}{l}1.68(1.04 \\
2.72)\end{array}$ & \\
\hline Yes & 556 & 1.0 & $\begin{array}{l}1.67(1.03, \\
2.71)\end{array}$ & $\begin{array}{l}3.08(1.94, \\
4.86)\end{array}$ & \\
\hline
\end{tabular}




\begin{tabular}{|c|c|c|c|c|c|}
\hline PTCA/PCI & & & & & 0.2614 \\
\hline No & 313 & 1.0 & $\begin{array}{l}1.19(0.71, \\
1.99)\end{array}$ & $\begin{array}{l}1.73(1.10 \\
2.74)\end{array}$ & \\
\hline Yes & 485 & 1.0 & $\begin{array}{l}1.69(1.02 \\
2.80)\end{array}$ & $\begin{array}{l}3.08(1.89, \\
5.02)\end{array}$ & \\
\hline gender & & & & & 0.7209 \\
\hline Female & 294 & 1.0 & $\begin{array}{l}1.37(0.76 \\
2.47)\end{array}$ & $\begin{array}{l}2.82(1.65, \\
4.83)\end{array}$ & \\
\hline Male & 504 & 1.0 & $1.57(1.00,2.47)$ & $\begin{array}{l}2.52(1.65 \\
3.86)\end{array}$ & \\
\hline Race & & & & & 0.5510 \\
\hline White & 518 & 1.0 & $\begin{array}{l}1.43(0.88 \\
2.34)\end{array}$ & $\begin{array}{l}2.84(1.85, \\
4.38)\end{array}$ & \\
\hline Black & 46 & 1.0 & $\begin{array}{l}2.63(0.66 \\
10.56)\end{array}$ & $\begin{array}{l}6.29(1.49 \\
26.52)\end{array}$ & \\
\hline Other & 234 & 1.0 & $\begin{array}{l}1.26(0.70 \\
2.25)\end{array}$ & $\begin{array}{l}1.99(1.14 \\
3.48)\end{array}$ & \\
\hline $\operatorname{ALT}(\mathrm{U} / \mathrm{L})$ & & & & & 0.6194 \\
\hline$<35.81$ & 393 & 1.0 & $\begin{array}{l}1.35(0.80 \\
2.28)\end{array}$ & $\begin{array}{l}2.88(1.80 \\
4.64)\end{array}$ & \\
\hline$\geq 35.81$ & 405 & 1.0 & $\begin{array}{l}1.57(0.95 \\
2.58)\end{array}$ & $\begin{array}{l}2.41 \text { (1.51, } \\
3.86)\end{array}$ & \\
\hline AST (U/L) & & & & & 0.8455 \\
\hline$<67.00$ & 391 & 1.0 & $\begin{array}{l}1.44(0.82 \\
2.52)\end{array}$ & $\begin{array}{l}2.84(1.71, \\
4.73)\end{array}$ & \\
\hline$\geq 67.00$ & 407 & 1.0 & $\begin{array}{l}1.45(0.91,2.32) \\
0\end{array}$ & $\begin{array}{l}2.40(1.55, \\
3.72)\end{array}$ & \\
\hline CK-peak (U/L) & & & & & 0.9398 \\
\hline$<823.00$ & 397 & 1.0 & $\begin{array}{l}1.46(0.88 \\
2.41)\end{array}$ & $\begin{array}{l}2.56(1.64, \\
4.01)\end{array}$ & \\
\hline$\geq 823.00$ & 401 & 1.0 & $\begin{array}{l}1.56(0.93 \\
2.63)\end{array}$ & $\begin{array}{l}2.81(1.71, \\
4.62)\end{array}$ & \\
\hline CK-MB-peak (U/L) & & & & & 0.9731 \\
\hline$<48.00$ & 398 & 1.0 & $\begin{array}{l}1.54(0.91 \\
2.60)\end{array}$ & $\begin{array}{l}2.69(1.68, \\
4.30)\end{array}$ & \\
\hline$\geq 48.00$ & 399 & 1.0 & $\begin{array}{l}1.45(0.89 \\
2.38)\end{array}$ & $\begin{array}{l}2.66(1.66, \\
4.28)\end{array}$ & \\
\hline
\end{tabular}


Glucose (mg/dL)

$<148.00$

$\geq 148.00$

PT (seconds)

$<13.70$

$\geq 13.70$

Hemoglobin $(\mathrm{g} / \mathrm{dL})$

$<12.40$

$\geq 12.40$

RDW (\%)

$<13.80$

$\geq 13.80$

Creatinine $(\mathrm{mEq} / \mathrm{L})$

$<1.10$

$\geq 1.10$

BUN (mg/dL)

$<22.00$

$\geq 22.00$

$\operatorname{WBC}\left(10^{9} / \mathrm{L}\right)$

$<12.00$

$\geq 12.00$

Potassium (mmol/L)
0.7956

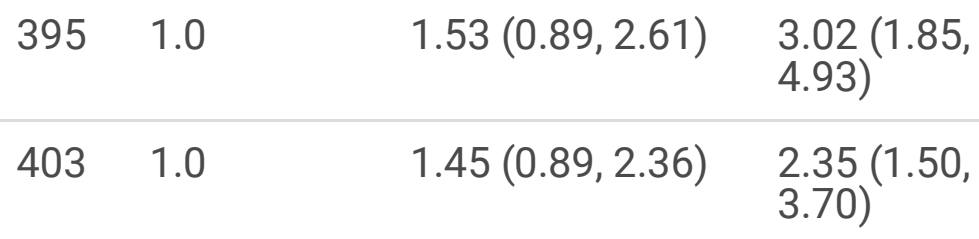

0.2151

$\begin{array}{llll}388 & 1.0 & 1.96(1.18,3.27) & 2.82(1.67, \\ & & & 4.78)\end{array}$

0.7119

$394 \quad 1.0$

$1.20(0.71,2.03) \quad 2.14(1.34$,

3.41)

$404 \quad 1.0$

$\begin{array}{ll}1.62(0.98,2.66) & 2.47(1.47, \\ & 4.15)\end{array}$

0.4510

$394 \quad 1.0$

$1.37(0.77,2.42) \quad 2.84(1.65$,

4.88)

$404 \quad 1.0$

$1.55(0.97,2.47) \quad 2.22(1.45$,

3.39)

0.6118

$303 \quad 1.0$

$1.76(0.91,3.42) \quad 3.61(1.91$,

$6.84)$

$399 \quad 1.0$

$1.69(1.05,2.73)$

$2.58(1.66$,

4.02)

0.1007

$370 \quad 1.0$

2.26 (1.21,

4.21)

$3.86(2.07$,

7.20)

$414 \quad 1.0$

$1.11(0.70$,

1.75)

$1.84(1.23$,

2.77)

0.3940

$3.13(1.85$,

5.29)

$1.38(0.77$,

2.46)

2.10 (1.32,

$3.35)$
$1.40(0.85$,

2.31)

0.5270 


\begin{tabular}{|c|c|c|c|c|c|}
\hline$<4.20$ & 388 & 1.0 & $\begin{array}{l}1.22(0.71, \\
2.08)\end{array}$ & $\begin{array}{l}2.43(1.48, \\
3.98)\end{array}$ & \\
\hline$\geq 4.20$ & 410 & 1.0 & $1.83(1.13,2.97)$ & $\begin{array}{l}2.90(1.85, \\
4.54)\end{array}$ & \\
\hline Sodium (mmol/L) & & & & & 0.8463 \\
\hline$<139.00$ & 384 & 1.0 & $\begin{array}{l}1.64(0.97 \\
2.78)\end{array}$ & $\begin{array}{l}\text { 2.91 (1.77, } \\
4.78)\end{array}$ & \\
\hline$\geq 139.00$ & 414 & 1.0 & $\begin{array}{l}1.35(0.82 \\
2.24)\end{array}$ & $\begin{array}{l}2.46(1.57 \\
3.85)\end{array}$ & \\
\hline Platelet $\left(10^{9} / \mathrm{L}\right)$ & & & & & 0.9992 \\
\hline$<241.00$ & 399 & 1.0 & $\begin{array}{l}1.50(0.90 \\
2.49)\end{array}$ & $\begin{array}{l}2.68(1.70 \\
4.21)\end{array}$ & \\
\hline$\geq 241.00$ & 399 & 1.0 & $\begin{array}{l}1.51(0.91 \\
2.52)\end{array}$ & $\begin{array}{l}2.62 \text { (1.61, } \\
4.29)\end{array}$ & \\
\hline Age (years) & & & & & 0.0469 \\
\hline$<70.00$ & 394 & 1.0 & $\begin{array}{l}1.26(0.68 \\
2.32)\end{array}$ & $\begin{array}{l}3.42(1.99, \\
5.88)\end{array}$ & \\
\hline$\geq 70.00$ & 404 & 1.0 & $\begin{array}{l}1.58(1.01 \\
2.47)\end{array}$ & $\begin{array}{l}2.05(1.35, \\
3.12)\end{array}$ & \\
\hline Heart rate (beats/minute) & & & & & 0.0023 \\
\hline$<101.00$ & 385 & 1.0 & $\begin{array}{l}2.61(1.43, \\
4.77)\end{array}$ & $\begin{array}{l}5.12(2.89, \\
9.07)\end{array}$ & \\
\hline$\geq 101.00$ & 413 & 1.0 & $\begin{array}{l}0.92(0.59 \\
1.45)\end{array}$ & $\begin{array}{l}1.51(1.00 \\
2.28)\end{array}$ & \\
\hline $\begin{array}{l}\text { Respiratory rate } \\
\text { (beats/minute) }\end{array}$ & & & & & 0.8764 \\
\hline$<26.00$ & 368 & 1.0 & $\begin{array}{l}1.44(0.80 \\
2.58)\end{array}$ & $\begin{array}{l}2.83(1.65 \\
4.83)\end{array}$ & \\
\hline$\geq 26.00$ & 430 & 1.0 & $\begin{array}{l}1.54(0.98 \\
2.44)\end{array}$ & $\begin{array}{l}2.56(1.67 \\
3.90)\end{array}$ & \\
\hline $\mathrm{MBP}(\mathrm{mmHg})$ & & & & & 0.4178 \\
\hline$<57.00$ & 371 & 1.0 & $\begin{array}{l}1.16(0.70 \\
1.92)\end{array}$ & $\begin{array}{l}2.23(1.43, \\
3.46)\end{array}$ & \\
\hline$\geq 57.00$ & 427 & 1.0 & $\begin{array}{l}1.87(1.12, \\
3.13)\end{array}$ & $\begin{array}{l}2.79(1.68, \\
4.66)\end{array}$ & \\
\hline Weight (kg) & & & & & 0.6674 \\
\hline$<78.00$ & 392 & 1.0 & $1.76(1.04$ & $3.01(1.84$ & \\
\hline
\end{tabular}




\begin{tabular}{|c|c|c|c|c|c|}
\hline & & & 2.97) & $4.91)$ & \\
\hline$\geq 78.00$ & 406 & 1.0 & $\begin{array}{l}1.26(0.76 \\
2.08)\end{array}$ & $\begin{array}{l}2.32(1.46 \\
3.69)\end{array}$ & \\
\hline ICU LOS (day) & & & & & 0.0002 \\
\hline$<3.69$ & 399 & 1.0 & $\begin{array}{l}1.28(0.73 \\
2.25)\end{array}$ & $\begin{array}{l}4.33(2.66, \\
7.03)\end{array}$ & \\
\hline$\geq 3.69$ & 399 & 1.0 & $\begin{array}{l}1.40(0.87 \\
2.27)\end{array}$ & $\begin{array}{l}1.59(1.01 \\
2.52)\end{array}$ & \\
\hline SAPS II & & & & & 0.0010 \\
\hline$<31.00$ & 247 & 1.0 & $\begin{array}{l}8.90(2.01 \\
39.44)\end{array}$ & $\begin{array}{l}19.22(4.30 \\
85.91)\end{array}$ & \\
\hline$\geq 31.00,<45$ & 278 & 1.0 & $\begin{array}{l}1.10(0.58 \\
2.08)\end{array}$ & $\begin{array}{l}1.33(0.72 \\
2.45)\end{array}$ & \\
\hline$\geq 45$ & 273 & 1.0 & $\begin{array}{l}0.96(0.60 \\
1.54)\end{array}$ & $\begin{array}{l}1.44(0.95 \\
2.18)\end{array}$ & \\
\hline SOFA & & & & & 0.0605 \\
\hline$<3.00$ & 247 & 1.0 & $\begin{array}{l}2.17(0.92, \\
5.11)\end{array}$ & $\begin{array}{l}5.29(2.19 \\
12.78)\end{array}$ & \\
\hline$\geq 3.00,<6.00$ & 236 & 1.0 & $\begin{array}{l}1.91(0.96 \\
3.82)\end{array}$ & $\begin{array}{l}1.75(0.88 \\
3.50)\end{array}$ & \\
\hline$\geq 6.00$ & 315 & 1.0 & $\begin{array}{l}0.95(0.58 \\
1.54)\end{array}$ & $\begin{array}{l}1.53(1.00 \\
2.33)\end{array}$ & \\
\hline Urine output (ml/24h) & & & & & 0.2991 \\
\hline$<1805.00$ & 399 & 1.0 & $\begin{array}{l}1.26(0.79 \\
2.01)\end{array}$ & $\begin{array}{l}1.84(1.21 \\
2.82)\end{array}$ & \\
\hline$\geq 1805.00$ & 399 & 1.0 & $\begin{array}{l}1.54(0.87 \\
2.73)\end{array}$ & $\begin{array}{l}3.20(1.86, \\
5.50)\end{array}$ & \\
\hline
\end{tabular}

HR: hazard ratio; Cl: confidence interval. AF: atrial fibrillation; CHF: chronic heart failure; CDK: chronic kidney disease; COPD: chronic obstructive pulmonary disease; CAD: coronary artery disease; prior MI: prior myocardial infarction; ACEI/ARBs: angiotensin-converting enzyme inhibitor/angiotensin receptor blockers; PTCA/PCl: Percutaneous transluminal coronary angioplasty/percutaneous coronary intervention; ALT: alanine aminotransferase; AST: aspartate aminotransferase; CK: creatine kinase; CKMB: MB isoenzyme of creatine kinase; PT: prothrombin time; RDW: Red Cell Distribution Width; BUN: blood urea nitrogen; WBC: white blood cell; MBP: mean blood pressure; ICU LOS: length of ICU stay; SAPS II: simplified acute physiology score II; SOFA: sequential organ failure assessment score.

\section{Figures}




\section{2,699 ICU admissions}

Excluded the multiple ICU admission of each patient(16,223 excluded)

Excluded patients who was lack of albumin and neutrophil percentage data(28,167 excluded)

Excluded patients' diagnosis without AMI (17,502 excluded)

Excluded patients whose age was below 18years-old(0 excluded)

Excluded patients died before admission ( 9 excluded)

AMl patients from MIMIC-III database

(798)

Figure 1

Flow chat of study selection. ICU: intensive care unit; AMI: acute myocardial infarction. MIMIC III: Medical Information Mart for Intensive Care III. 


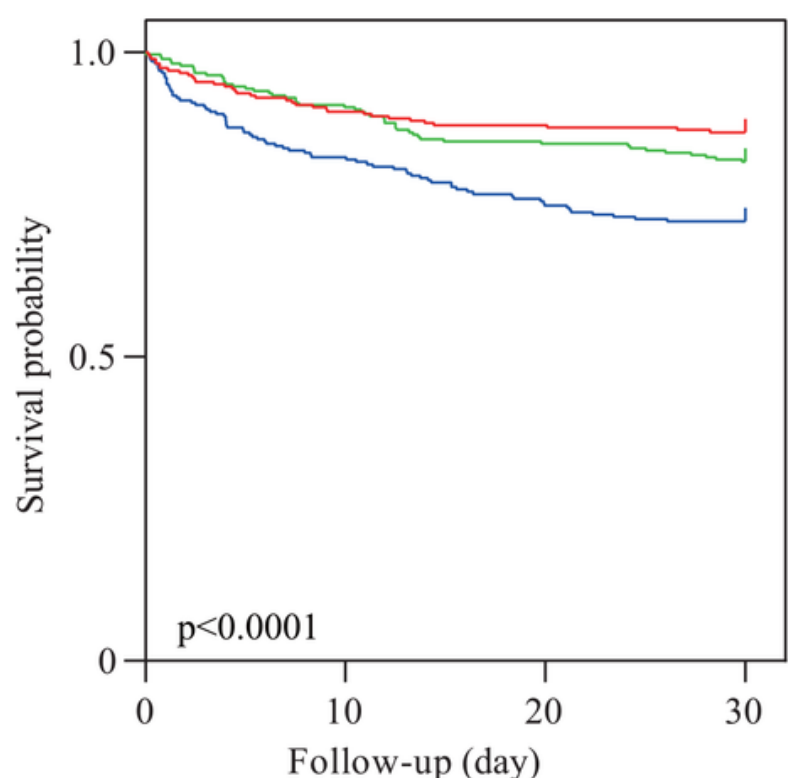

$\perp$ Tertile $1:$ NPAR $<21.58$

$\perp$ Tertile $2: 21.58 \leq \mathrm{NPAR}<26.77$

$\perp$ Tertile 3:NPAR $\geq 26.77$

( a)

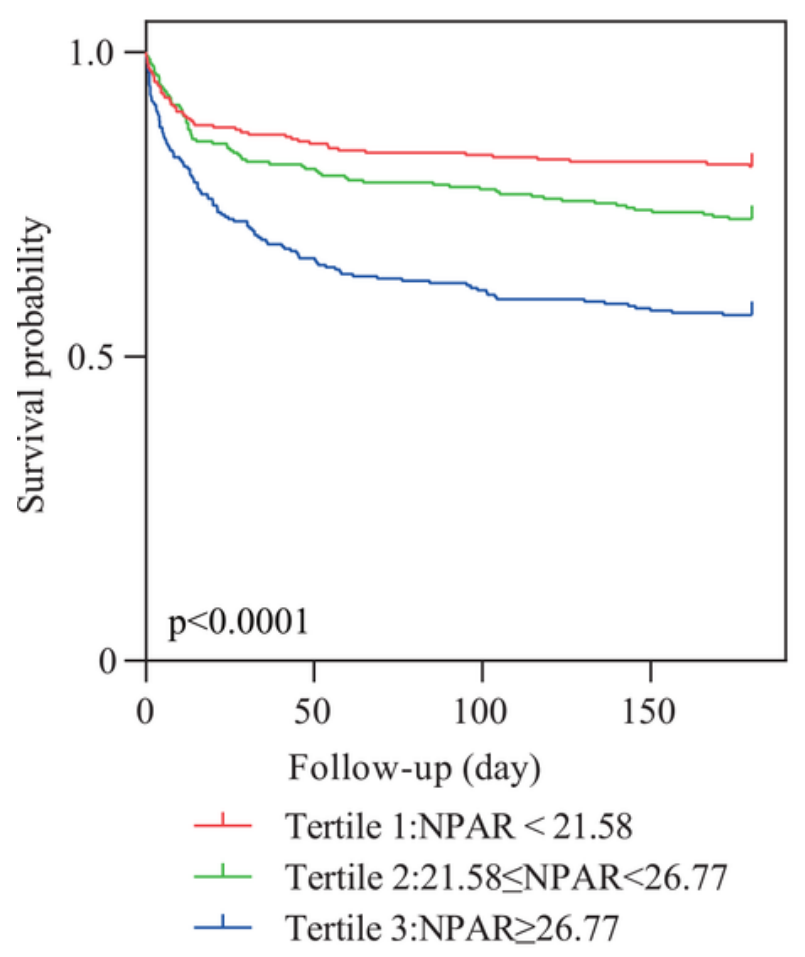

(c)

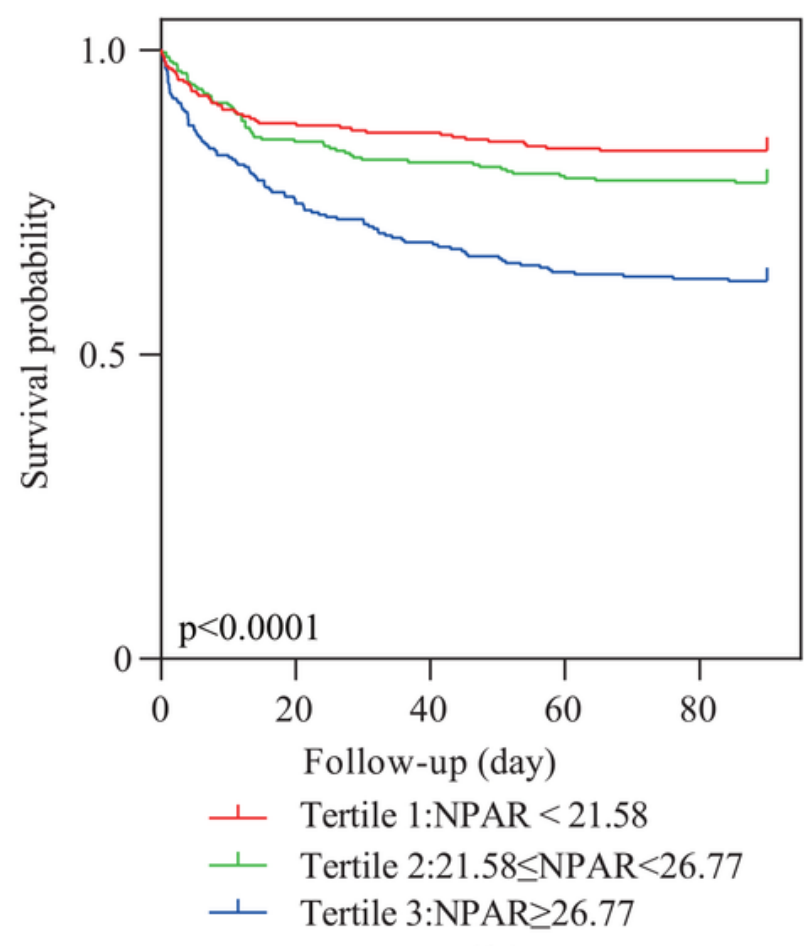

(b)

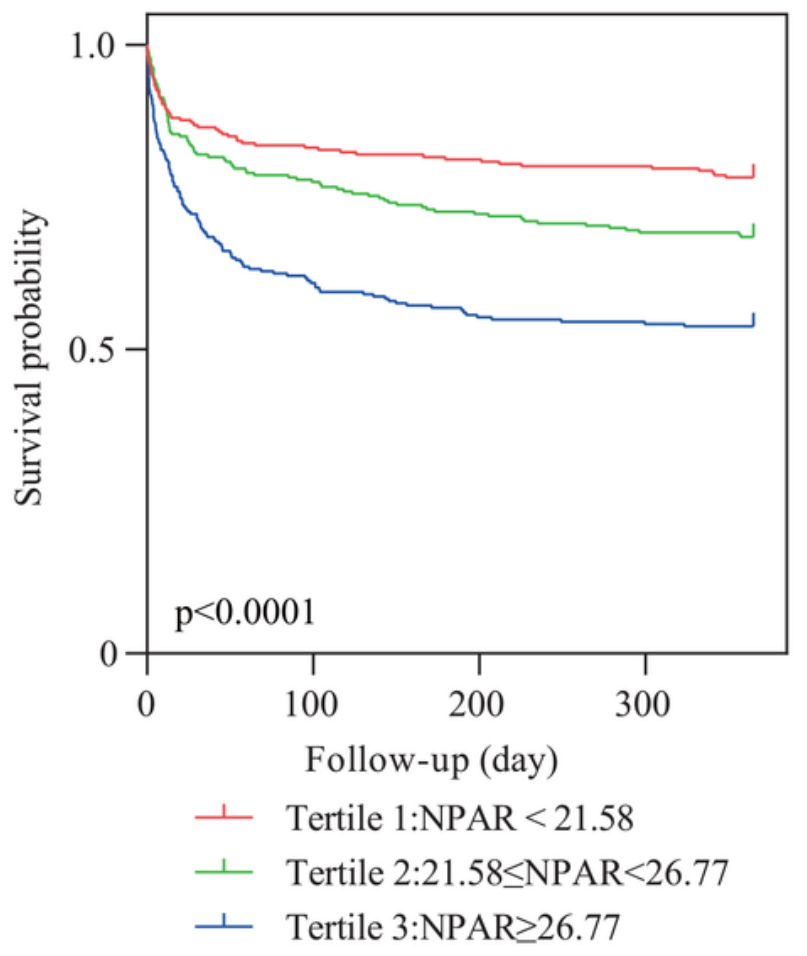

(d)

Figure 2

Survival probability and Kaplan-Meier curves of three admission NPAR groups. (a) 30-day. (b) 90-day. (c) 180-day. (d) 365-day. NPAR: neutrophil percentage-albumin ratio. 


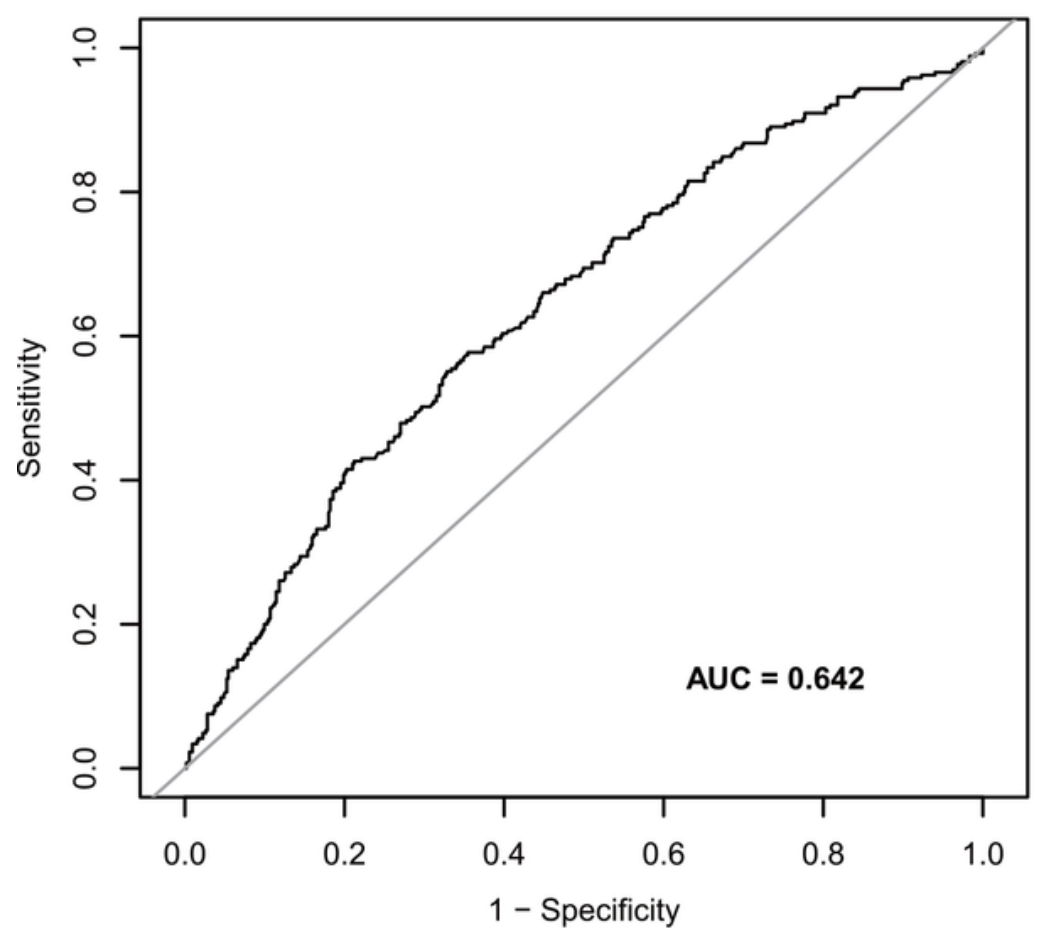

(a)

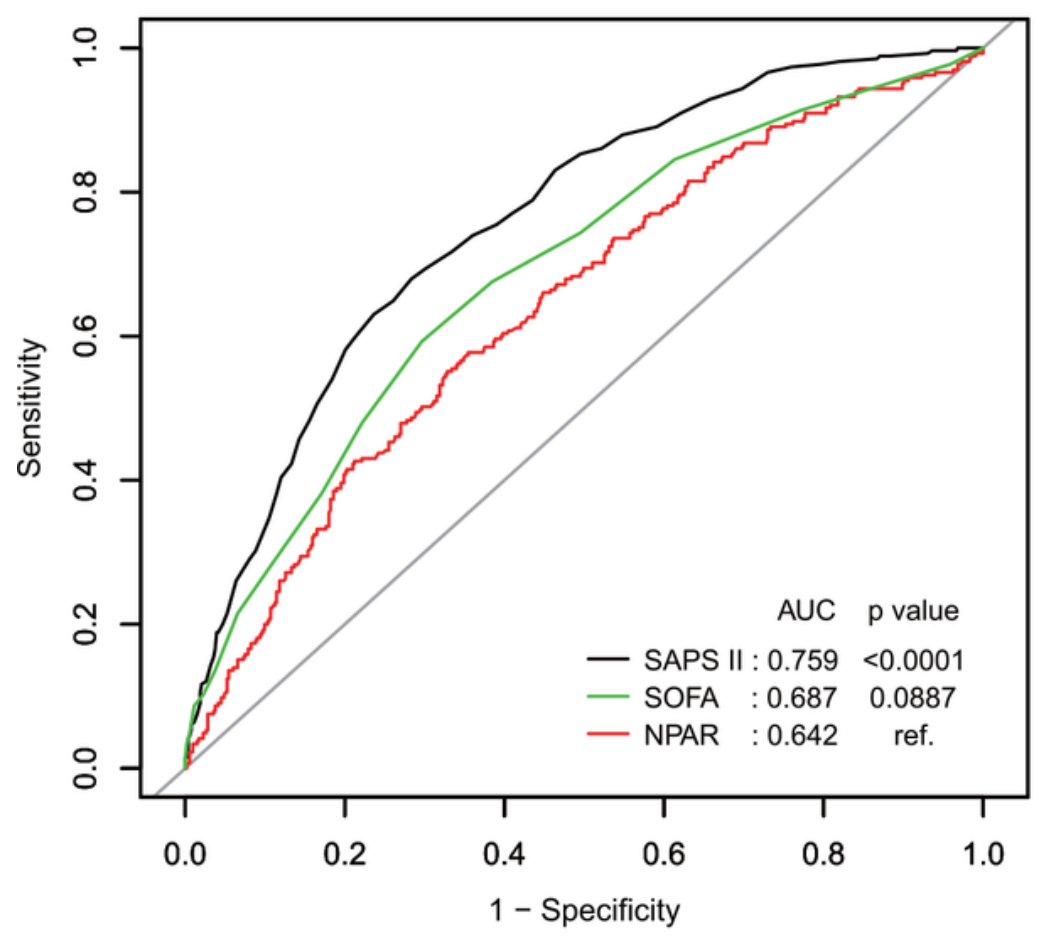

(b)

\section{Figure 3}

ROC curves for the prediction of 365-day all-cause mortality. (a) about NPAR. (b) about NPAR, SAPS II score, and SOFA score. NPAR: neutrophil percentage-albumin ratio; SAPS II: simplified acute physiology score II; SOFA: sequential organ failure assessment score. 